\title{
Making beautiful music: The state of the art in mobile technology and how we can make the most of it in libraries
}

\author{
June 8, 2012
}
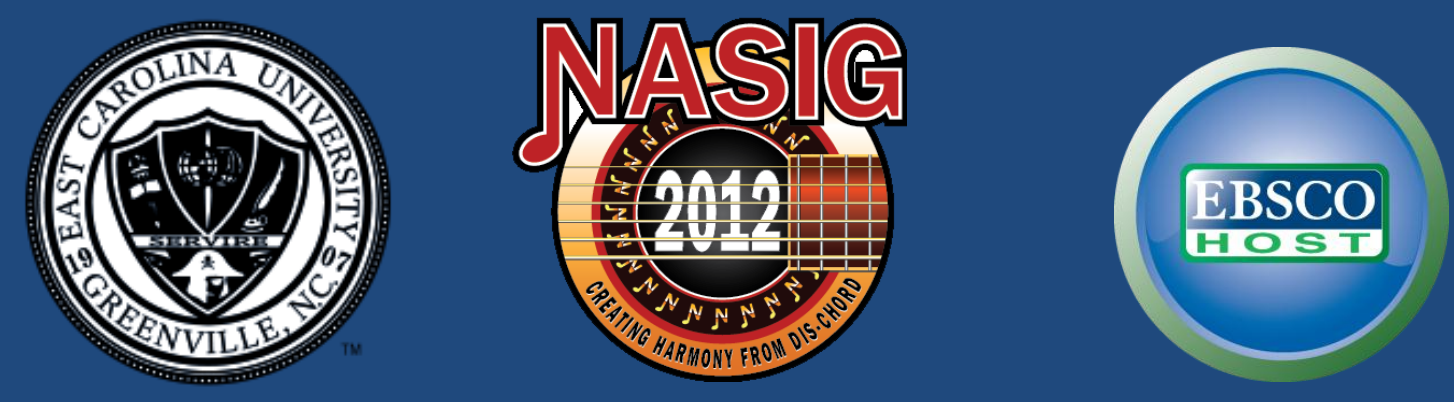

Eleanor I. Cook, East Carolina University

$\&$

Megan Hurst, EBSCO Publishing 


\section{Objectives}

- Define "mobile" (emphasis here on "smaller" devices)

- Trends

- Challenges \& opportunities of "portability"

- Meeting patrons where they're at

- Multiplicity of devices/formats

- Emerging standards

- One library's experience piloting e-readers and iPads

- The future of reading

- $\quad$ This will NOT be a session on how to set up a mobile site for a library 


\section{Audience Poll}

- Did you grow up analogue or digital?

- Do you own a "smart" cell phone?

- How many different electronic devices do you use in a typical day?

-What do you hope to learn from this session? 


\section{Definitions}

- Mobile App - an application that runs on a specific device which may not require an internet connection (works offline)

- Mobile Web Site - a web site that has been tuned for a mobile display and touch-based navigation (requires an Internet connection)

- Responsive Web Site - a web site that has been tuned to progressively disclose and stack user interface and content elements depending on the computer or device screen size

\begin{tabular}{|l|l|l|}
\hline Mobile WEB SITE pros & Mobile APP pros \\
\hline Ease of maintenance & \begin{tabular}{l} 
Offline access \\
\hline $\begin{array}{l}\text { Single design across } \\
\text { device types }\end{array}$
\end{tabular} & $\begin{array}{l}\text { Discoverability in app } \\
\text { market/store }\end{array}$ \\
\hline $\begin{array}{l}\text { No app market } \\
\text { approval processes }\end{array}$ & $\frac{5}{5}$ & $\begin{array}{l}\text { Supports richer } \\
\text { interactivity, } \\
\text { advanced features }\end{array}$ \\
\hline $\begin{array}{l}\text { No third-party app } \\
\text { store rules or changes }\end{array}$ & $\frac{1}{5}$ & $\begin{array}{l}\text { Tight integration } \\
\text { with device (UI, hardware } \\
\text { [e.g. GPS]) }\end{array}$ \\
\hline $\begin{array}{l}\text { Instant availability/no } \\
\text { updates required }\end{array}$ & $\begin{array}{l}\text { Total control (e.g. DRM, } \\
\text { programming language } \\
\text { suitability) }\end{array}$ \\
\hline
\end{tabular}




\section{Definitions (Continued)}

- (late 1990s) eReader: A hand-held electronic device dedicated to the experience of reading books in electronic format. Inherently supports at least one Digital Rights Management (DRM) scheme to protect eBooks from piracy.

- (2000s) Tablet: A hand-held computer in the form of a flat tablet; esp. one that accepts input through a stylus or a fingertip. (Source: Oxford English Dictionary)

- (2006) Smartphone: An electronic device that combines a cell phone with a hand-held computer, typically offering Internet access, data storage, e-mail capability, etc. Supports native and downloaded apps as well.

- (2011) Web-enabled eReader: An electronic device that combines a an eReader with a hand-held computer, that includes Internet access, etc. Some web-enabled eReaders, like the Kindle Fire, support native and downloaded apps as well. 


\section{"Mobile" \\ Is Here \\ To Stay, \\ Because...}



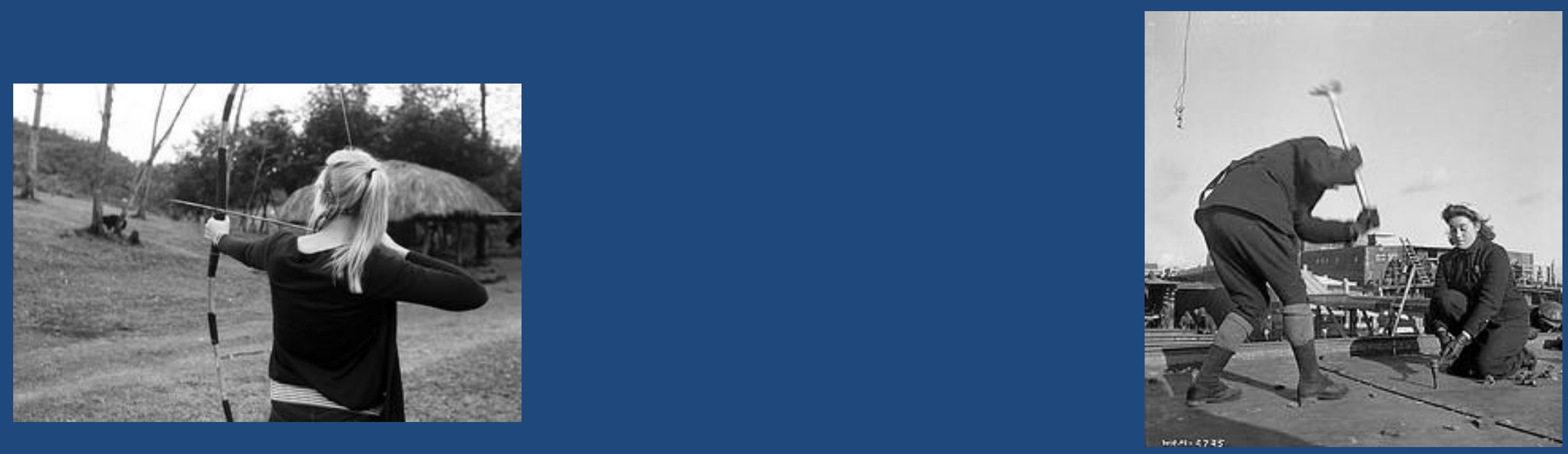

\section{Tools amplify human effectiveness. We only give them up}

\section{when there are better ones to replace them}

(or when the cost of using them is greater than the reward)

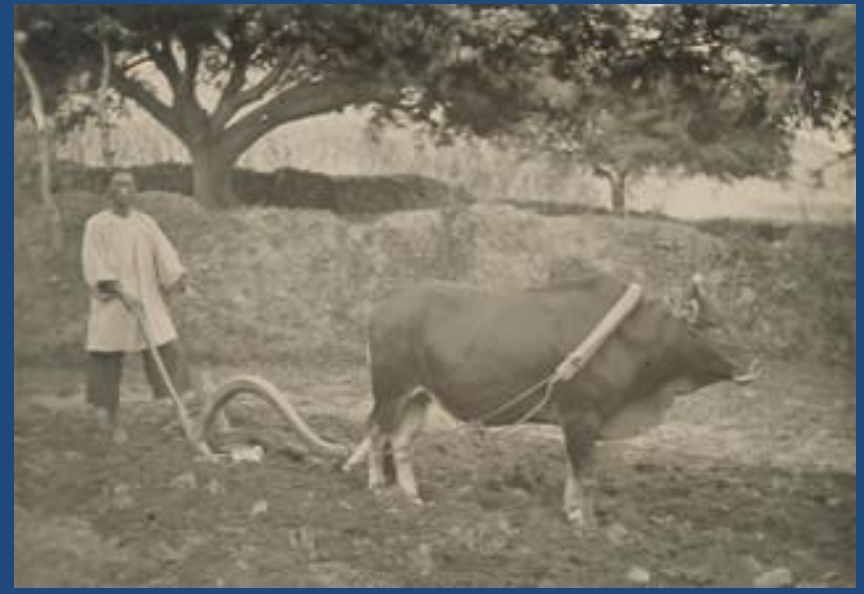

(top left) courtesy of Yiie

http://www.flickr.com/photos/yiie/

(left) courtesy of Thomas Fisher Rare Book Library

http://www.flickr.com/photos/thomasfisherlibrary/62 34739339/

(top right) courtesy of BiblioArchives and National Film Board of Canada

http://www.flickr.com/photos/lac-bac/ 

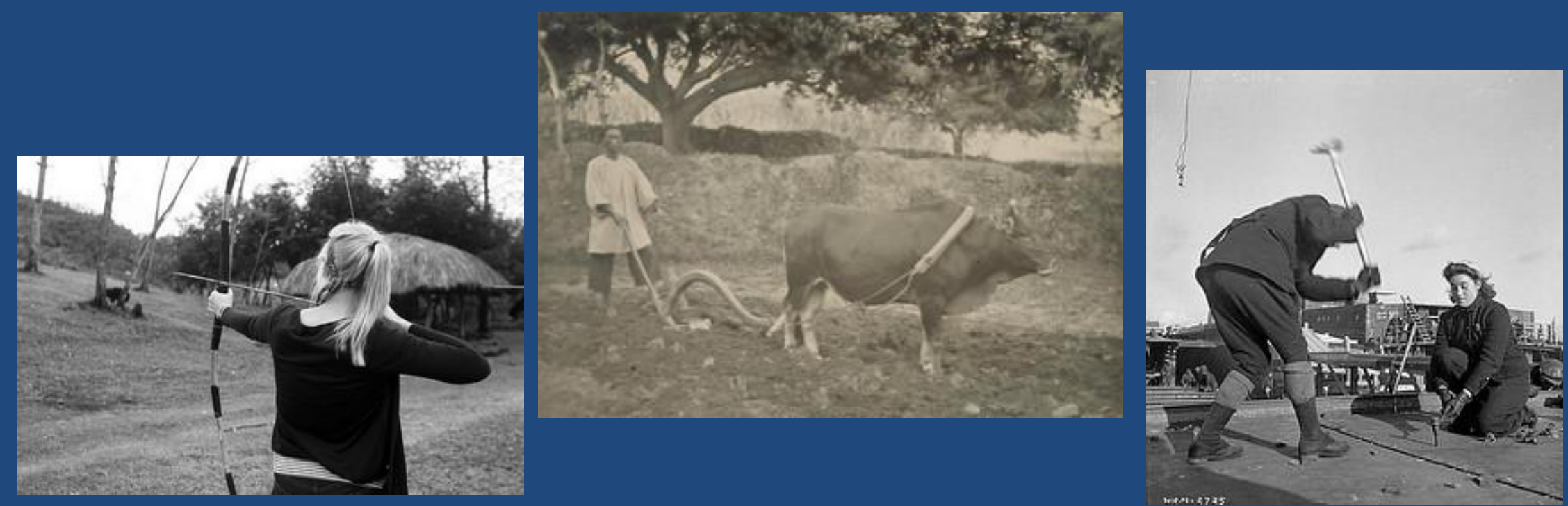

Now that we have tools for food and shelter...

Information is the most important tool.

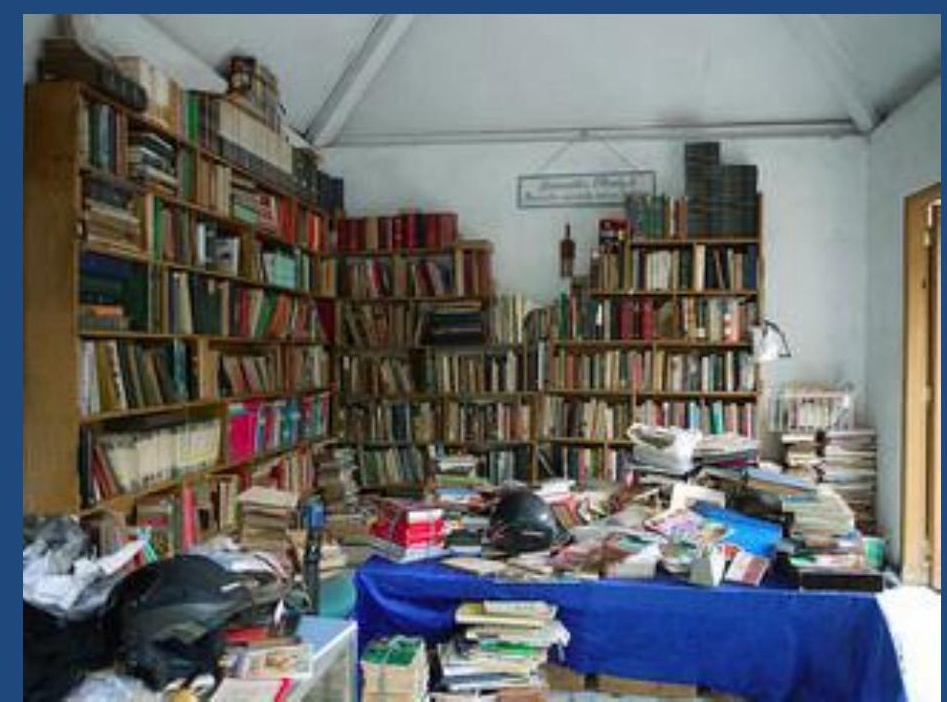




\section{These people need tools}

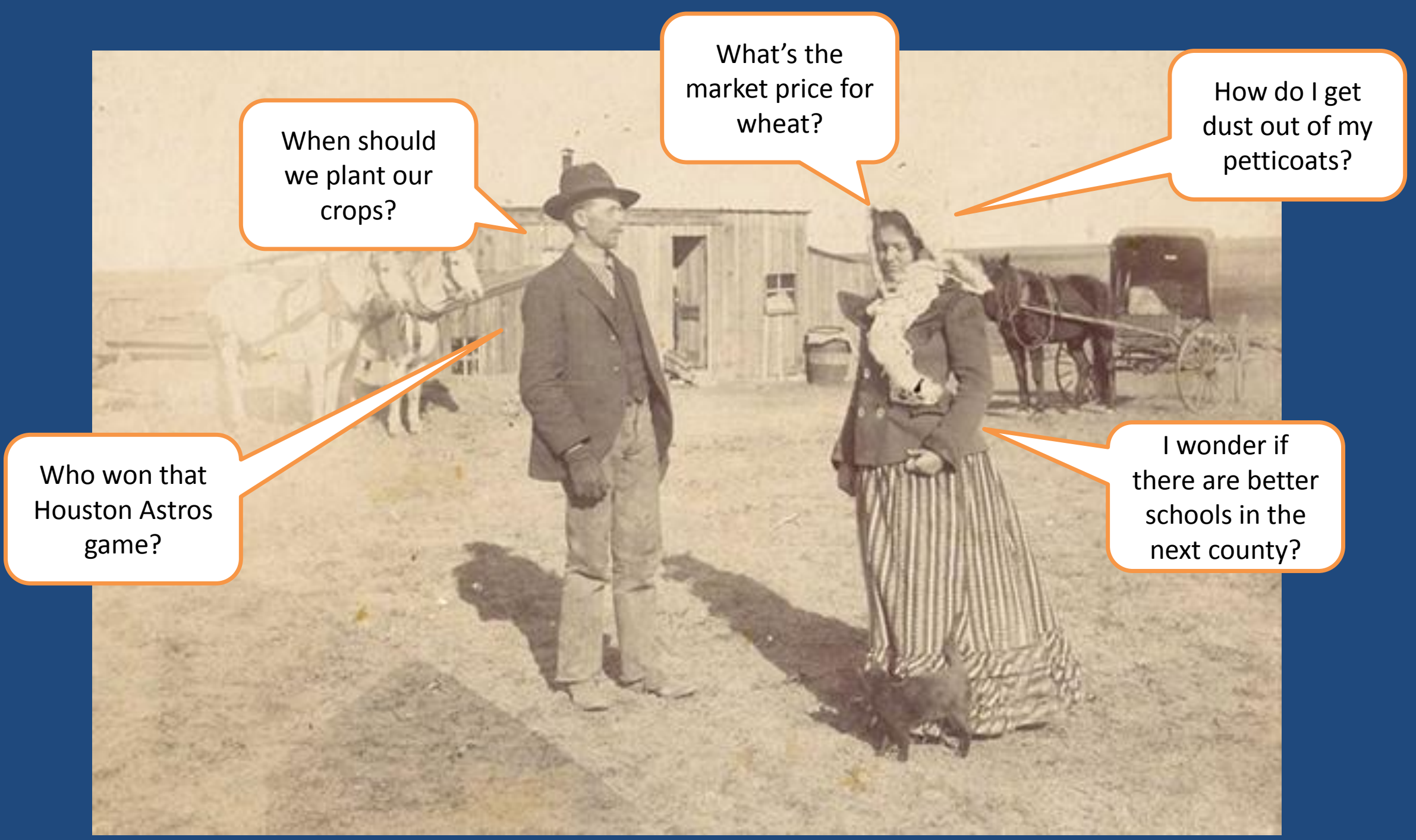




\section{Tools}
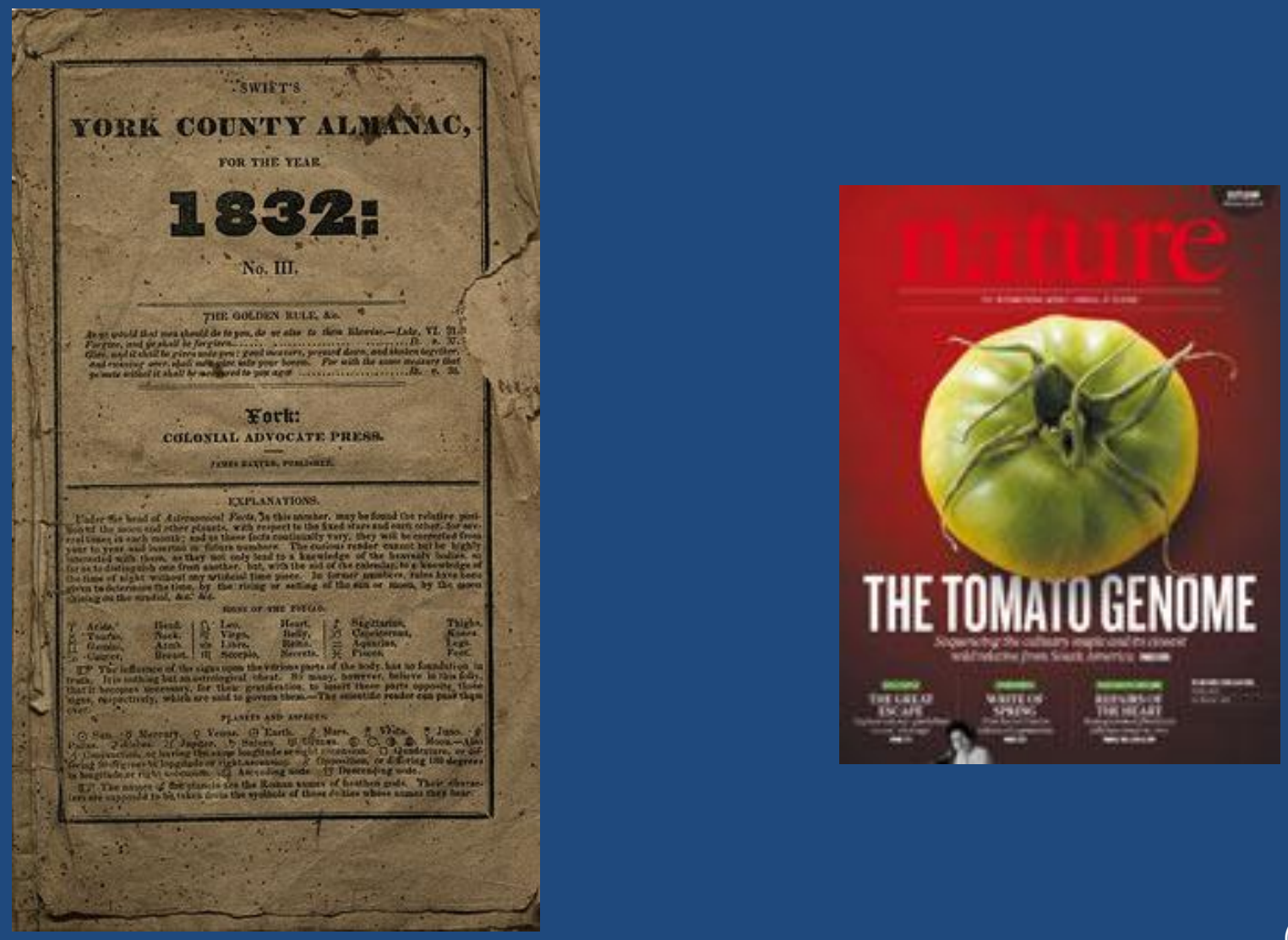

(left) Image courtesy of Special Collections, Waterloo Library http://www.flickr.com/photos/ 48169267@N08/4417459128/

(right) Image courtesy of Nature Naturejournal.com 


\section{And it's (still) about "access to tools"}

\section{WHOLE EARTH CATALOG}

access to tools

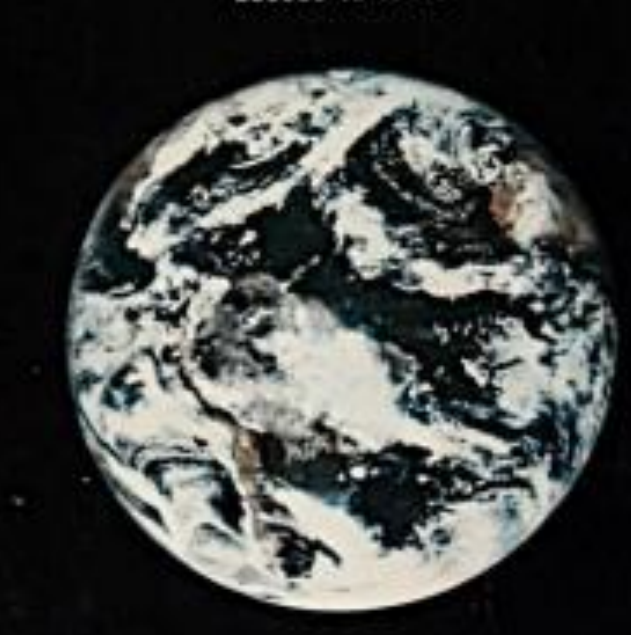

Fall 1968

$\$ 5$ 


\section{Access to Tools $=$ Libraries}

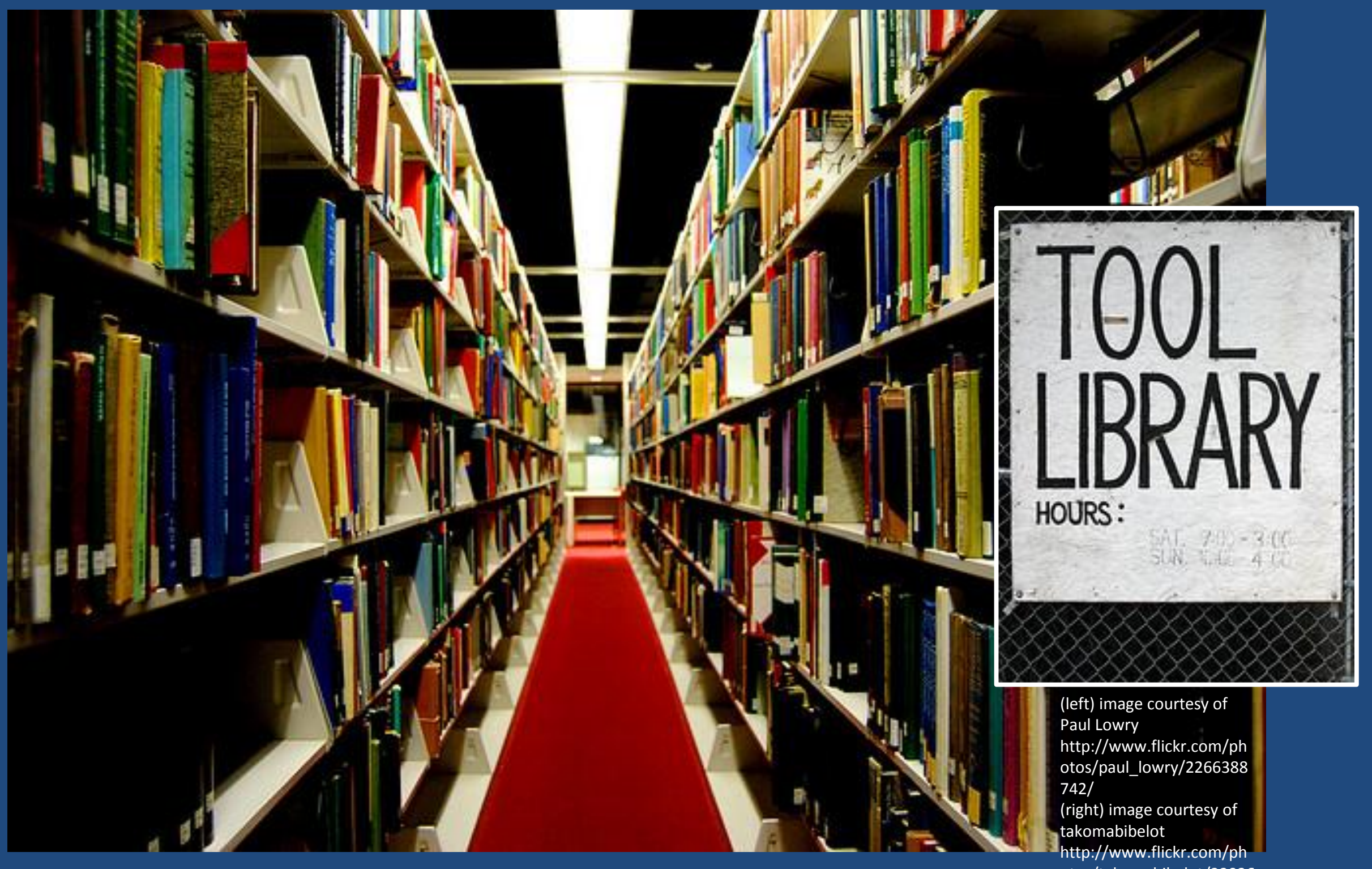




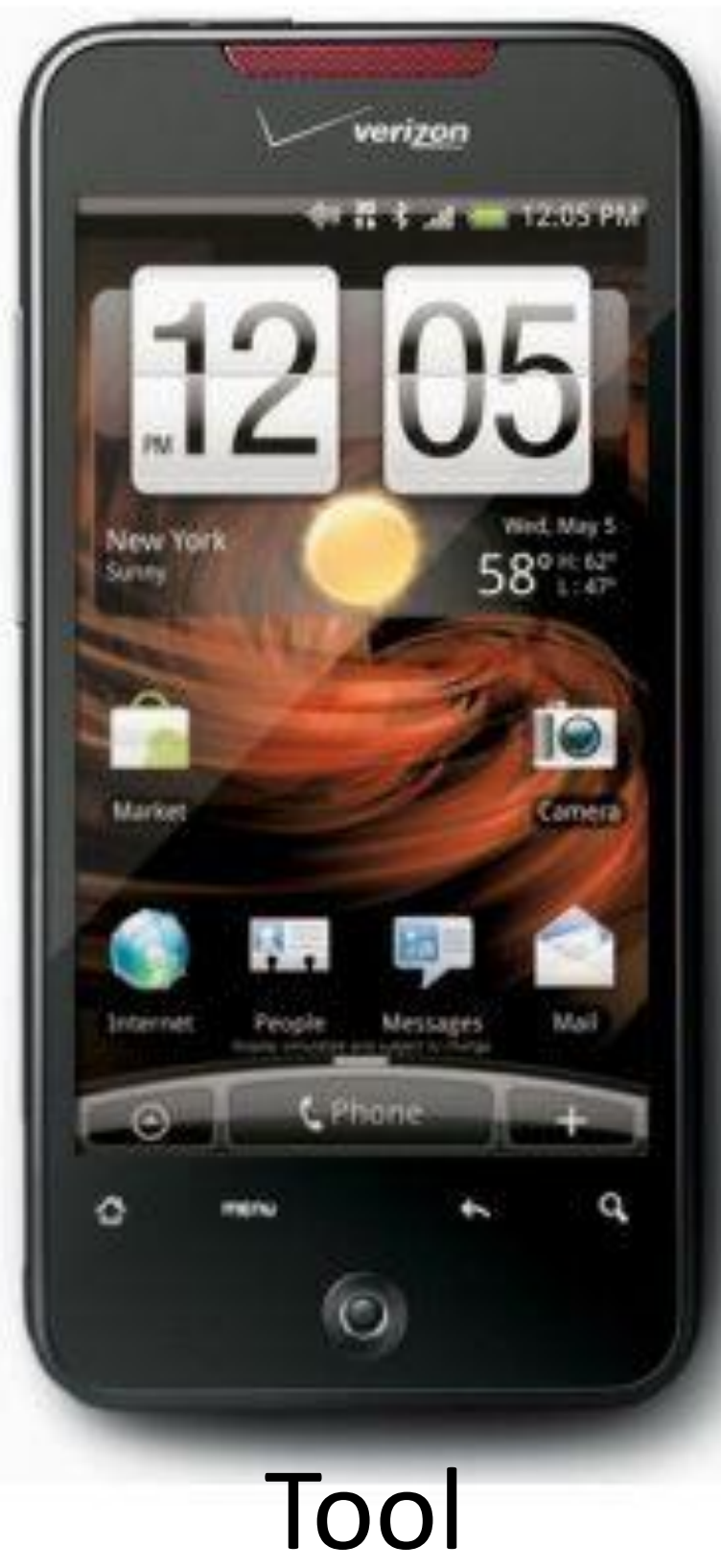




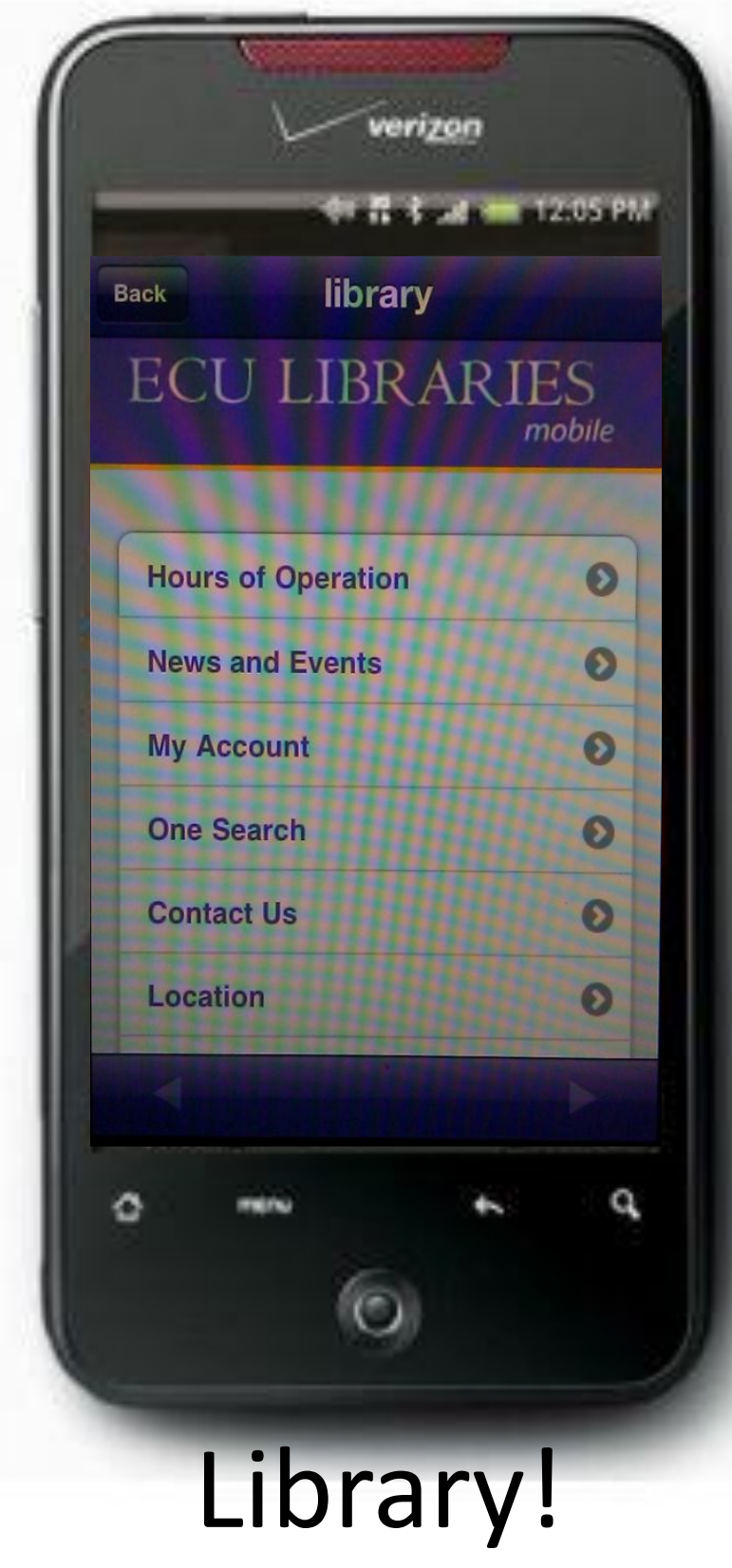




\section{Humans want}

to easily, quickly find information wherever they are now,

and then to easily, quickly access it wherever they want it in the future 


\title{
easily, quickly
}

\author{
wherever
}

now,

\section{easily, quickly}

wherever

in the future 


\section{easily \\ quickly}

here,

now

$+$

in the

future 


\section{What is EASILY, QUICKLY?}
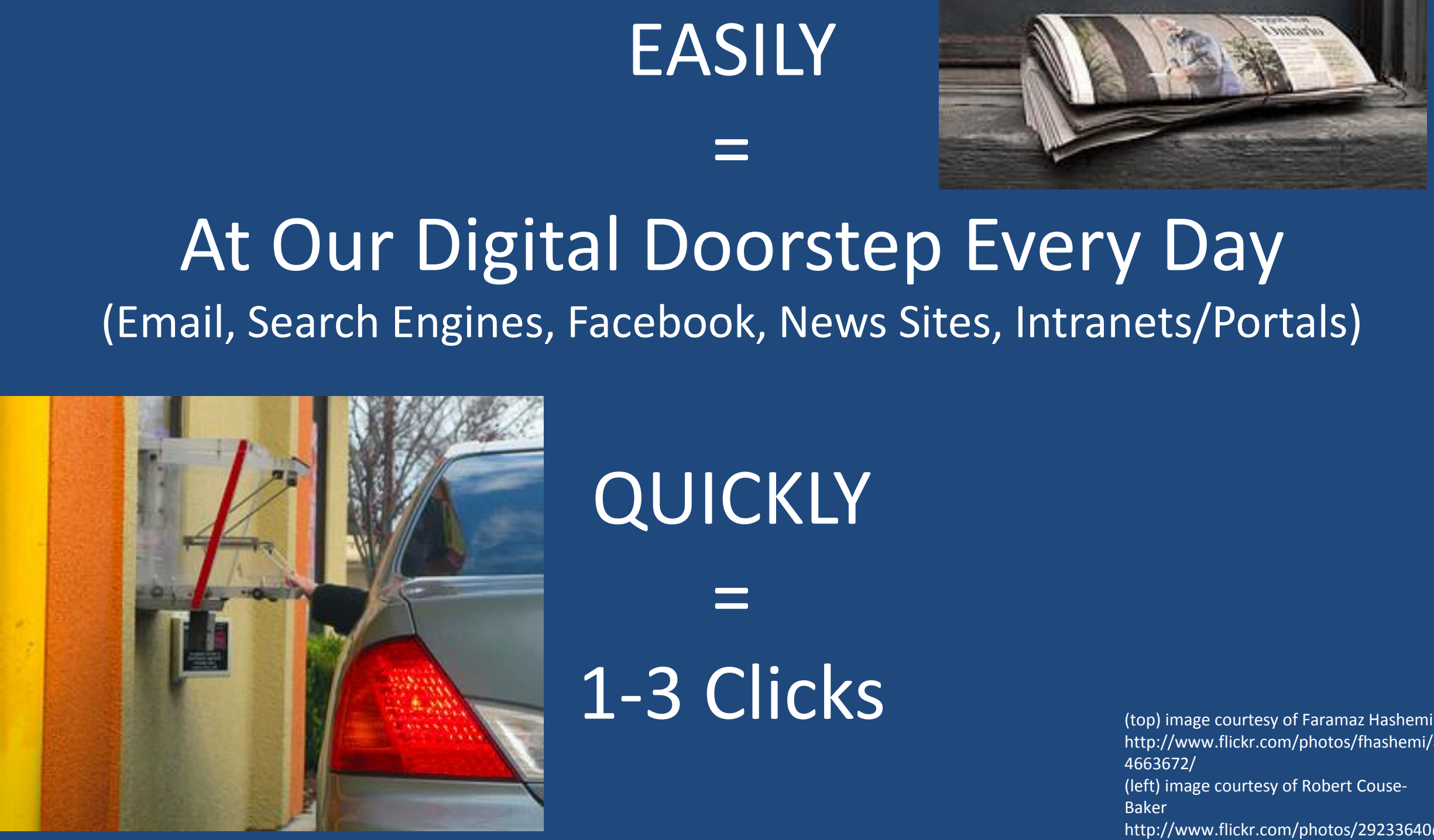

At Our Digital Doorstep Every Day

(Email, Search Engines, Facebook, News Sites, Intranets/Portals)

(top) image courtesy of Faramaz Hashemi http://www.flickr.com/photos/fhashemi/8 4663672/

(left) image courtesy of Robert Couse-

Baker

http://www.flickr.com/photos/29233640@ N07/3121350629/ 


\section{WHERE is HERE, NOW?}

Work/School

Home/Dorm

Commuting

Traveling

Leisure

Eating 
Share of Device Page Traffic for News Category (Weekday)

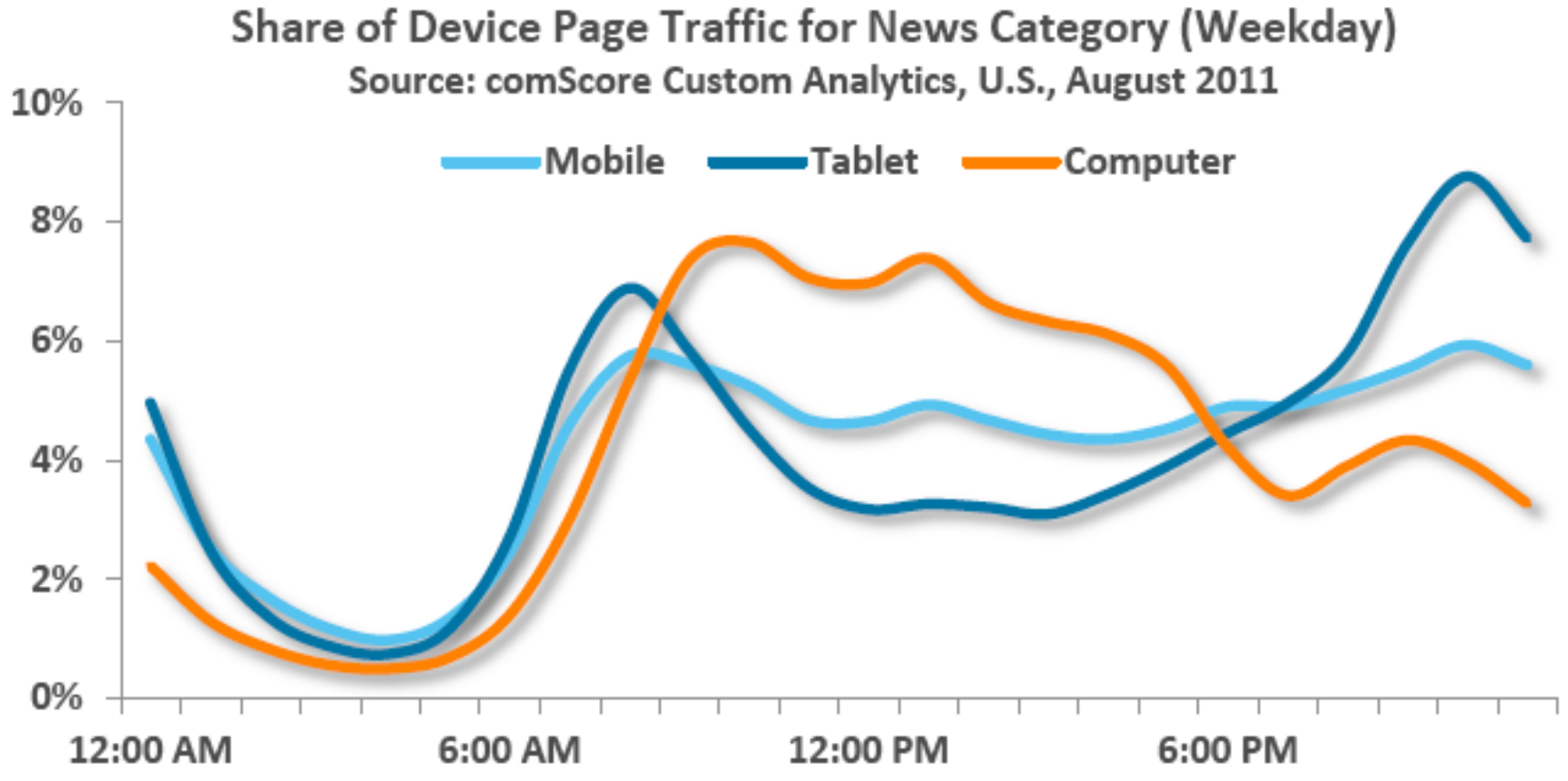

Share of Device Page Traffic for News Category (Weekend)

Source: comScore Custom Analytics, U.S., August 2011

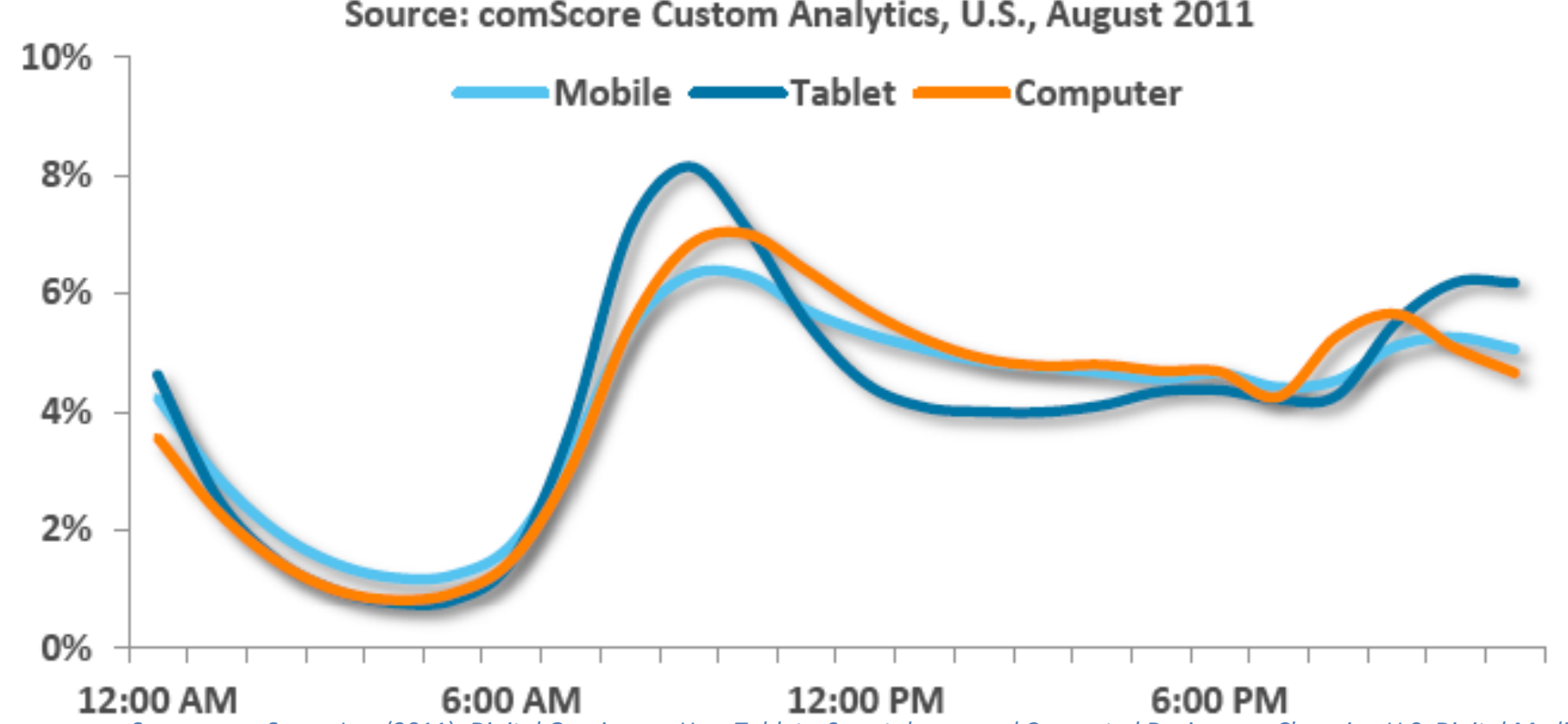

Source: comScore, Inc. (2011). Digital Omnivores: How Tablets, Smartphones and Connected Devices are Changing U.S. Digital Media (1) comSCORE Consumption Habits. http://www.comscore.com/Press Events/Presentations Whitepapers/2011/Digital Omnivores 


\section{How can I access my chosen information/tools IN THE FUTURE?}

In my library

or

In my daily workflow 


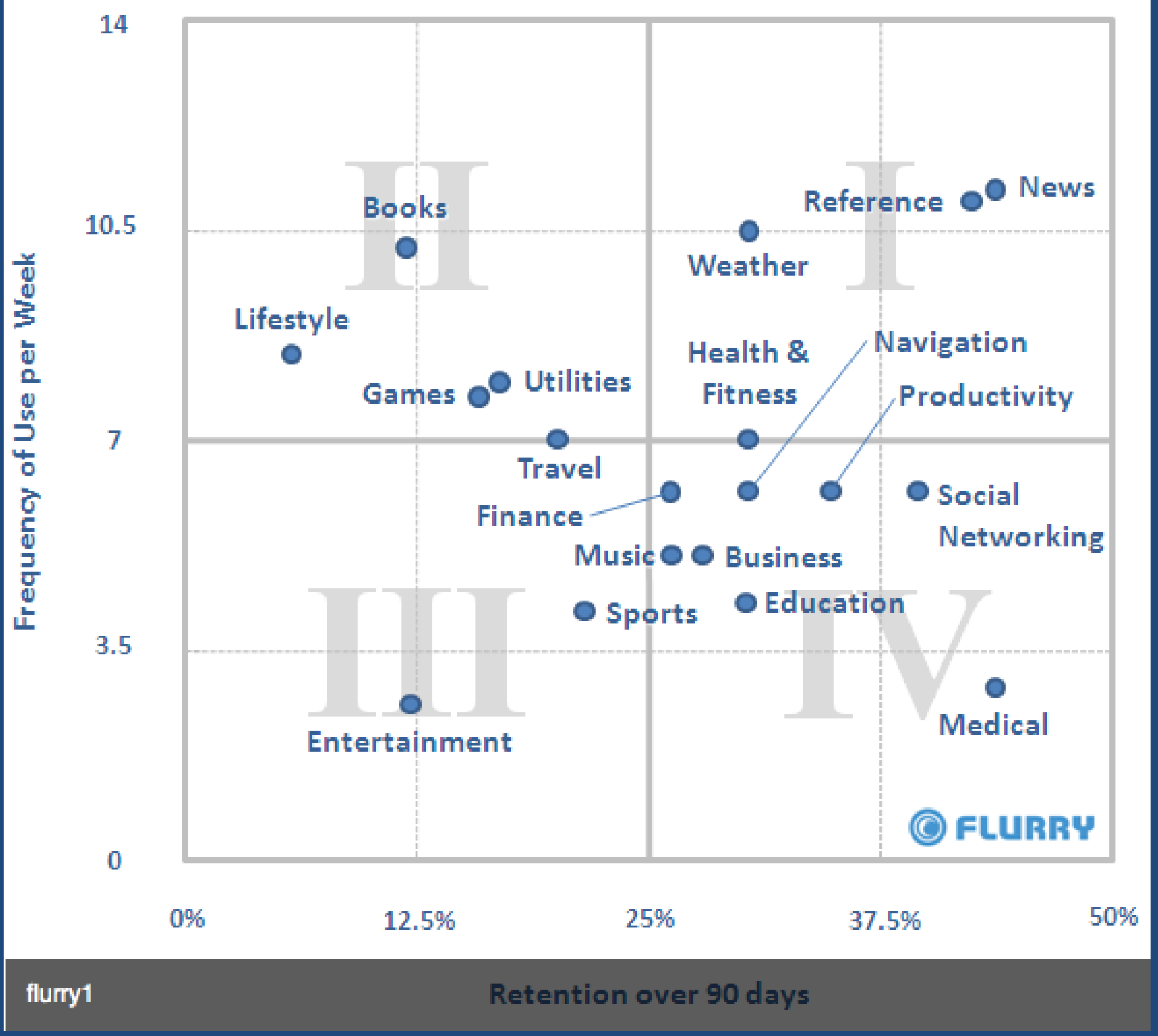




\section{When you read electronic books or e-books, do you ever read them on your...? \\ $\%$ of owners of each device who read e-books, and how frequently they read e-books on that device}

Daily or almost every day

Few times a month

Not read e-books on this device

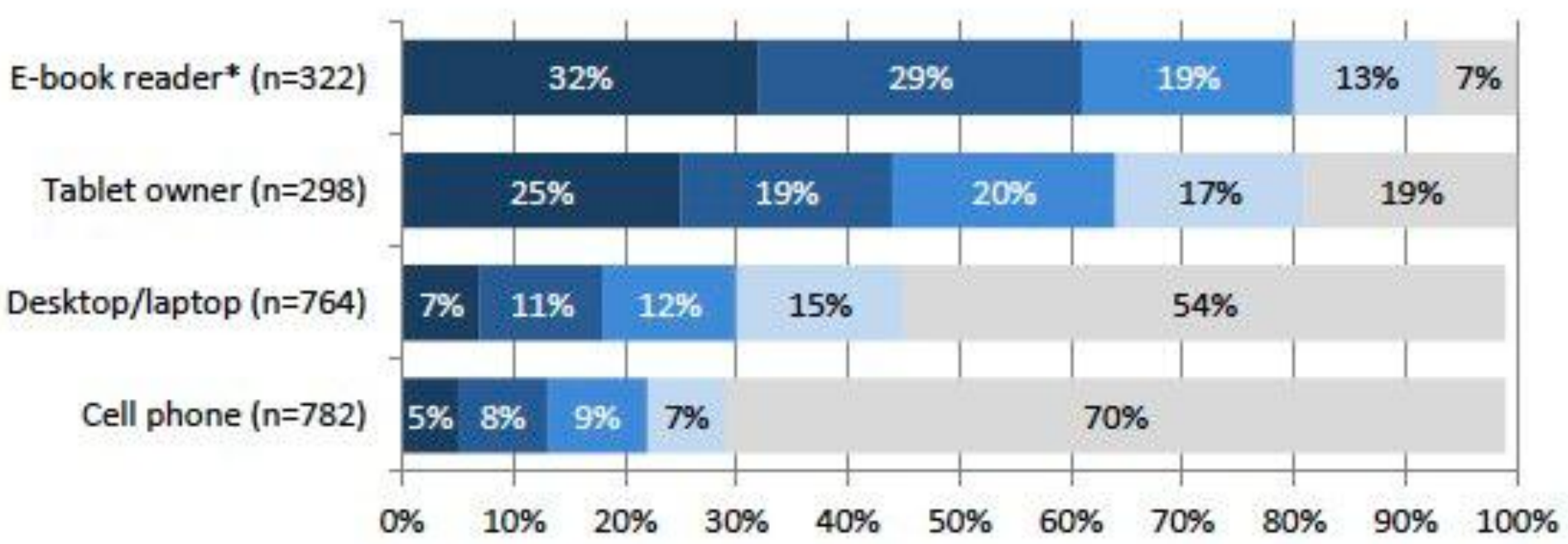

* Question was only asked of owners of each device who read e-books in general, so figures are \% of those who own that device

Source: Pew Research Center's Internet \& American Life Reading Habits Survey, November 16-December 21, 2011. $\mathrm{N}=2,986$ respondents age 16 and older. Interviews were conducted in English and Spanish and on landline and cells. The margin of error for the sample is $+/-2$ percentage points. 


\section{"Mobile"}

Matters

For Libraries

Because... 
Thinking about the last book you read, in any format, did you... $\%$ of American readers age 16t, as of December 2011

E Purchase it Borrow from friend/family Borrow from library Other

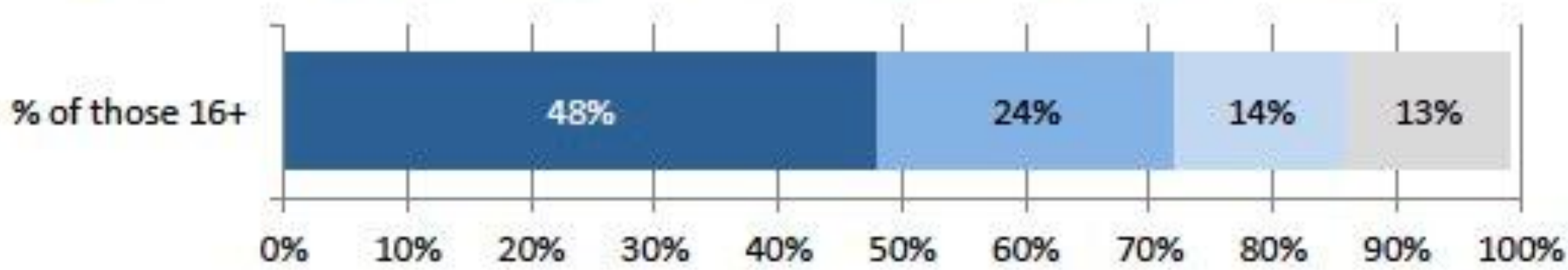

Source: Dec. 2011 results are from a survey of 2,986 people age 16 and older conducted November 16December 21, 2011. The survey was conducted in English and Spanish and on landline and cell phones. The margin of error is $+/-2$ percentage points. $\mathrm{N}$ for number of those who had read a book in the past 12 months $=2,474$.

\section{When you want to read a particular e-book, where do you look first?}

$\%$ of American e-book readers age 16t, as of December 2011

At an online bookstore/website $\|$ At your public library Someplace else Don't know

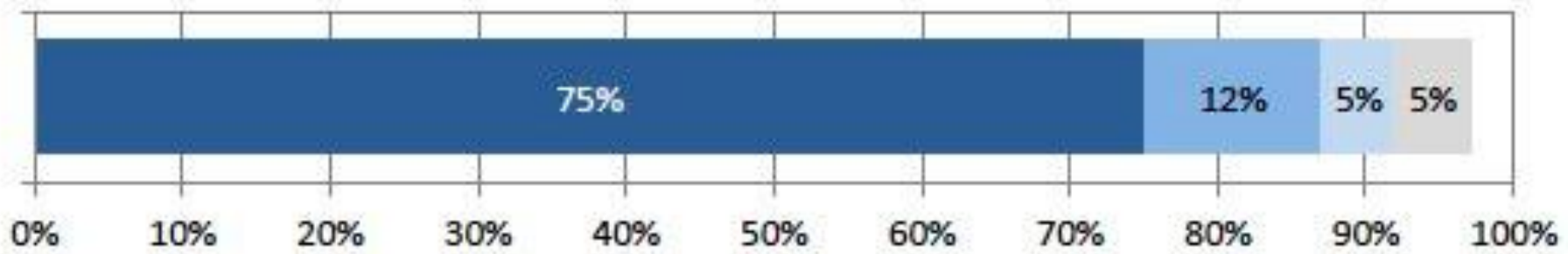

Source: Dec. 2011 results are from a survey of 2,986 people age 16 and older conducted November $16-$

December 21, 2011. $N$ for number of those who had read a book in the past 12 months=2,474 among those age 16 and older. The survey was conducted in English and Spanish and on landline and cell phones. The margin of error is $+/-2$ percentage points. 


\section{It's (still) about meeting library users wherever they're at...}

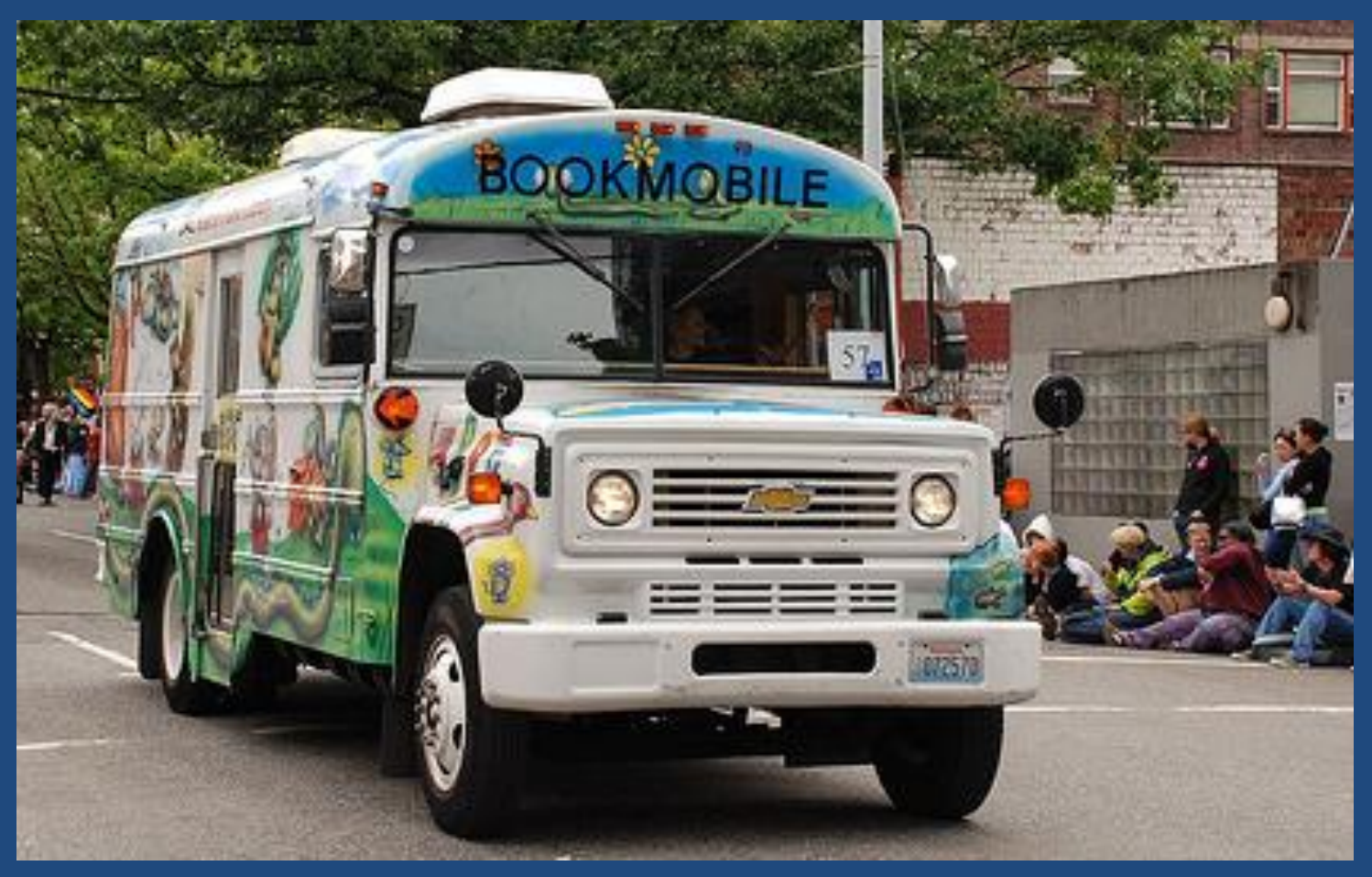




\section{Growth in mobile web traffic as percent of total web traffic}

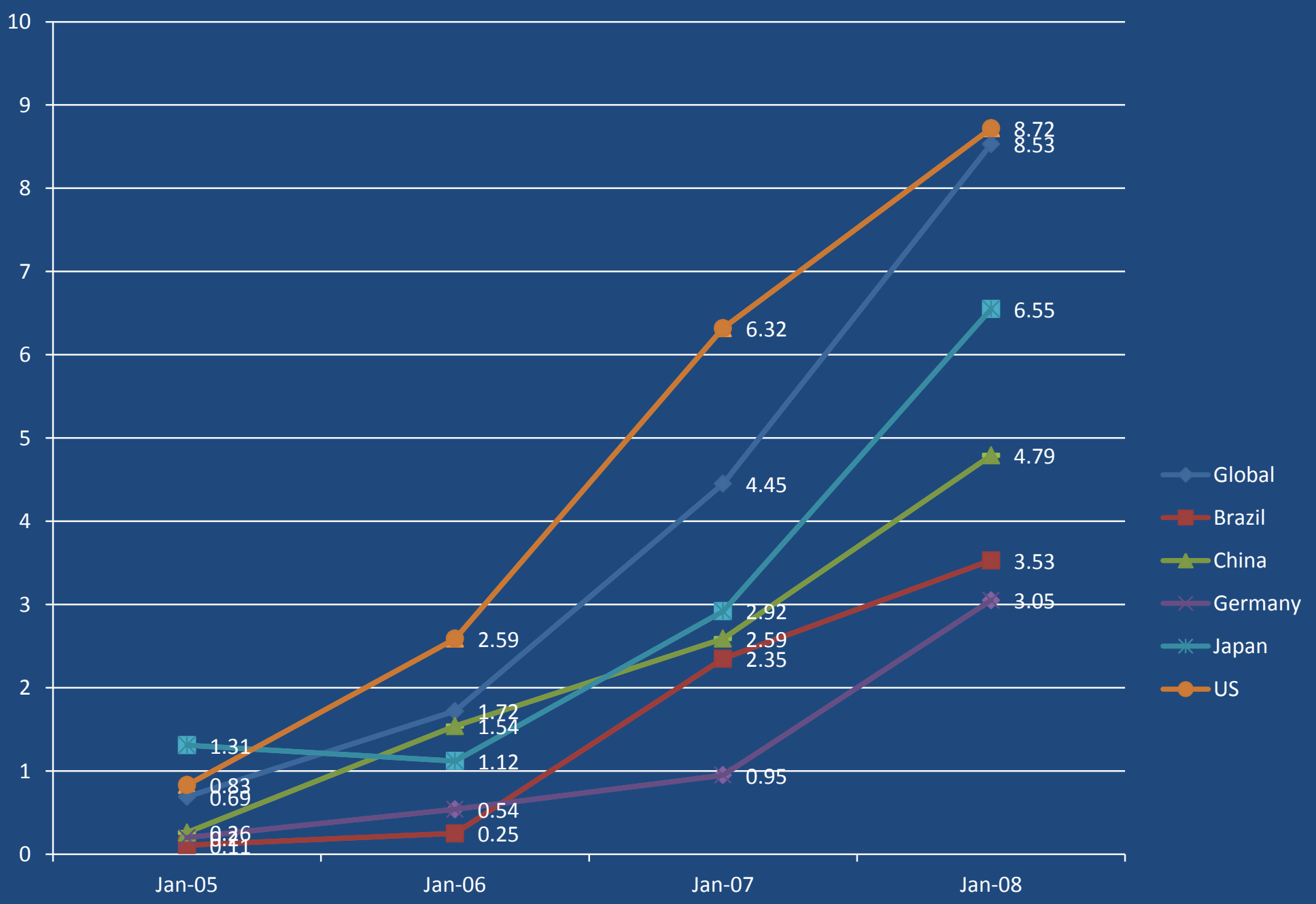

For this chart, "mobile" is defined as a pocket-sized computing device, typically having a display screen 12/4/2012vith touch input or a miniature keyboard. Source: GlobalStats, StatsCounter.com 


\section{Mobile Usage}

- Percentage of global web traffic attributed to mobile devices is $8.53 \% *$ to $13.4 \% * *$

- All stats sources show percentages almost doubling since a year ago

*Source StatsCounter.com, February 2012. Excludes tablets.

** Source Wikimedia, February 2012. Based on browser detection. 


\section{More Smartphones \& Tablets than People}

...the number of mobile devices rose by 9 percent in the first six months of 2011, to 327.6 million, which exceeds the number of people 315 million - who live in the U.S. and its territories. Internet traffic also rose 11 percent, to 341.2 billion megabytes during that time.

...According to the survey's data, people keep more than one wireless device, including smartphones and tablets, in their possession. Some analysts believe the surge comes from people having greater access to more of these devices, which have dropped in price and become more readily available. 


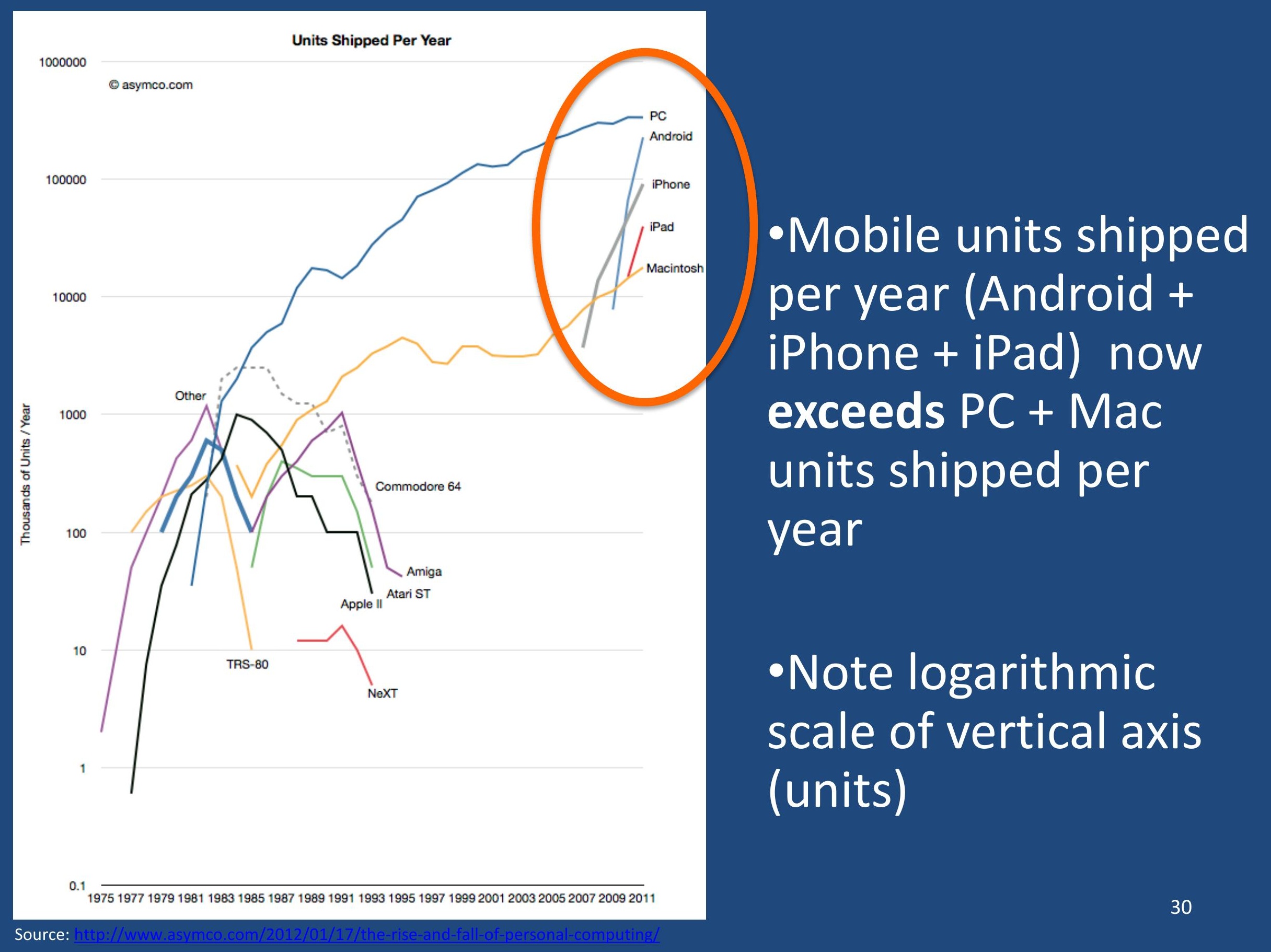




\section{Key Trends}

- Convergence of:

- Apps and Mobile Web Sites

- FinancialTimes.com

- Computer and Mobile Operating Systems

- Windows 8

- Mountain Lion

- HTML5

- Blurring lines between "online" and "offline"

- Tighter integration with devices

- More interactivity
- "Responsive" Web Sites

- BostonGlobe.com

- Open Standards

- MP3s

- EPUB \& DAISY

- Anti-DRM...?

- Apple iTunes moved to MP3

- "DRM-free" Publishers 


\section{Smartphone Platform War}

Market shares of smartphone Platforms

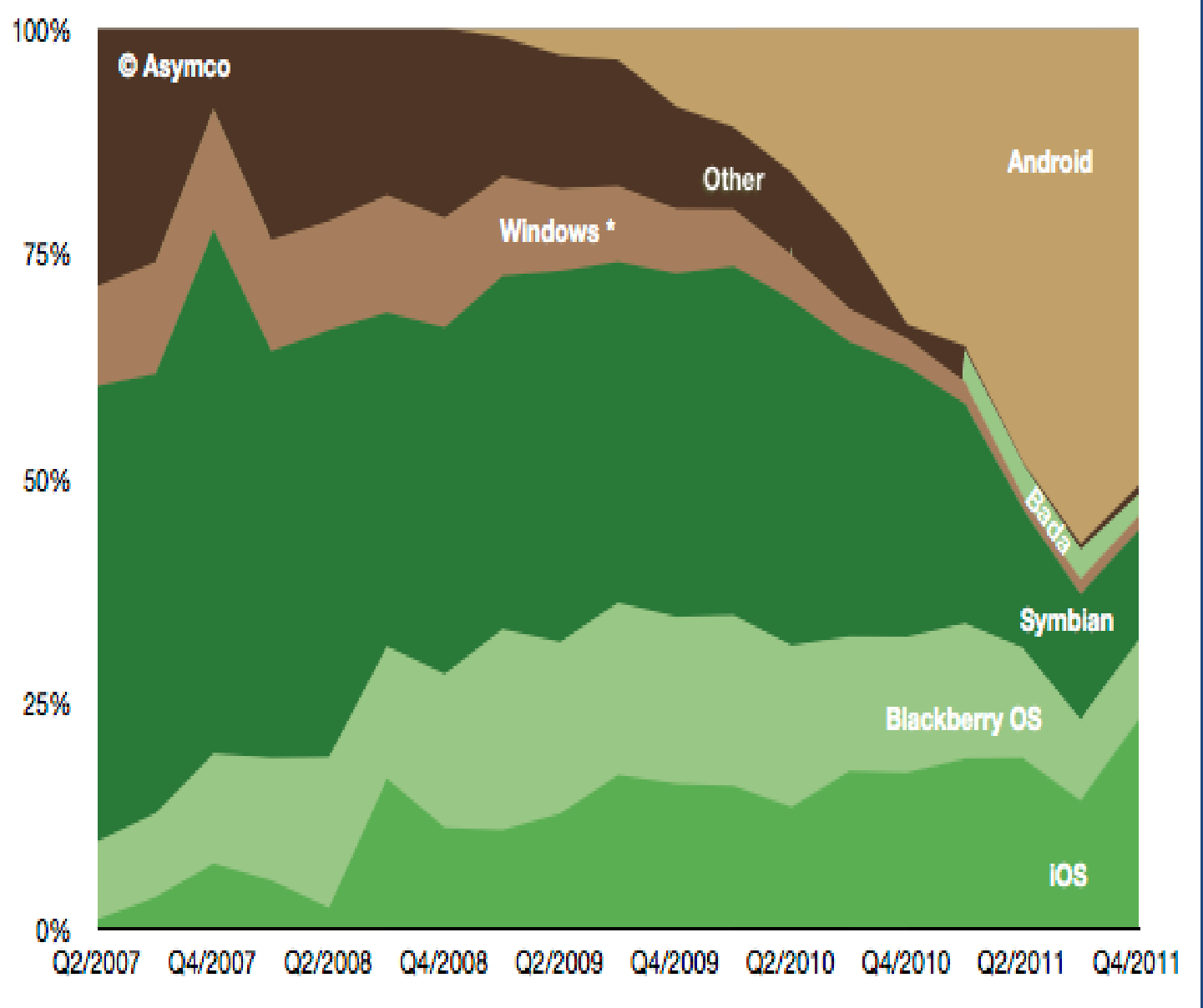

Up

- iOS

- Still exceeds Android in data usage

- Android

Down

- Blackberry

- Symbian

- But Nokia making bold bets with Lumia

- Windows

- Making bold bets with Windows8 


\section{Key Trends (US)}

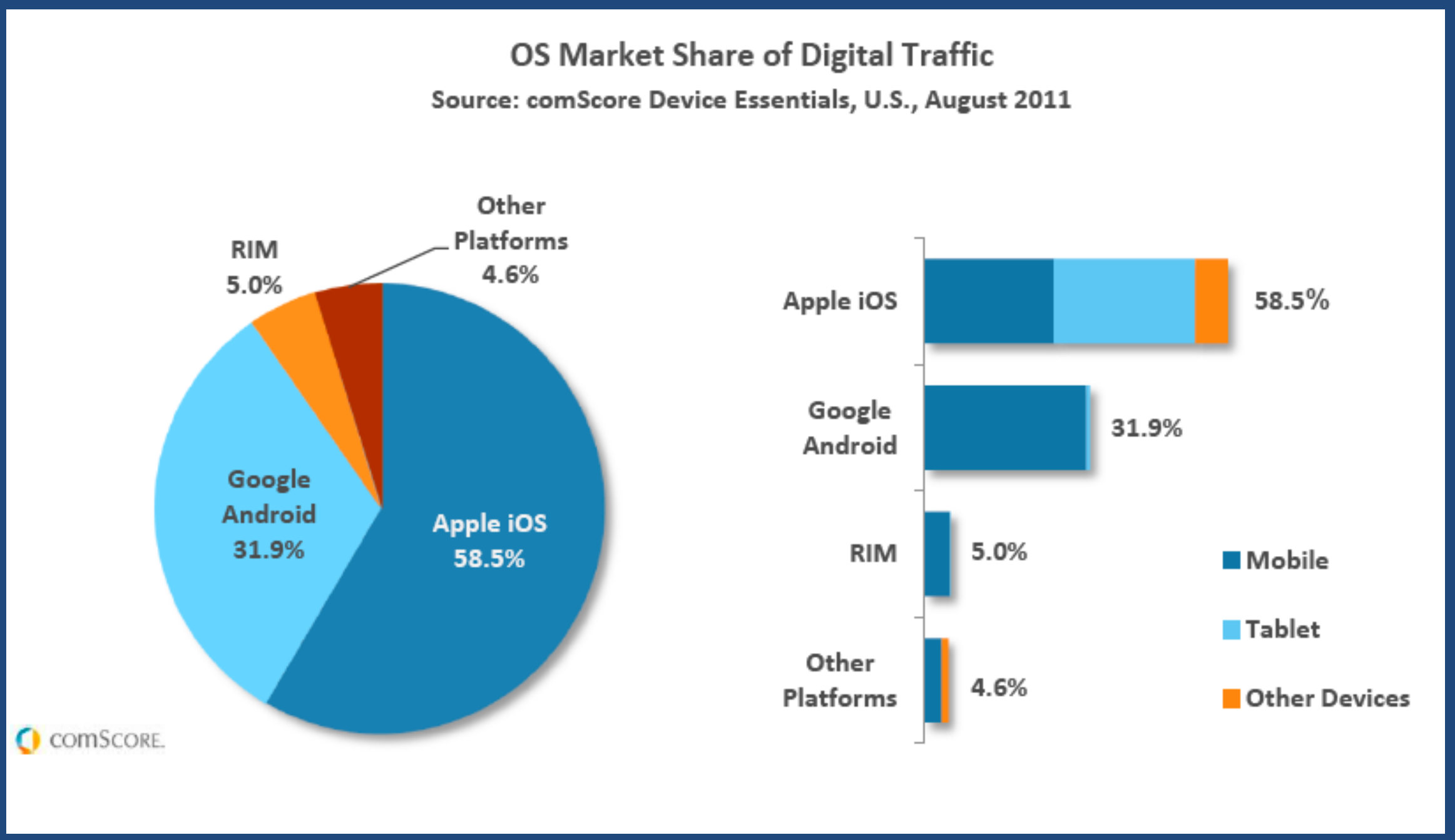

"Mobile" in this context means feature phones and smartphones. "Other Devices" means web-enabled gaming consoles, multimedia players, and eReaders. Source: comScore, Inc. (2011). Digital Omnivores: How Tablets, Smartphones and Connected Devices are Changing U.S. Digital Media Consumption Habits. http://www.comscore.com/Press Events/Presentations Whitepapers/2011/Digital Omnivores 


\title{
EASILY $=$
}

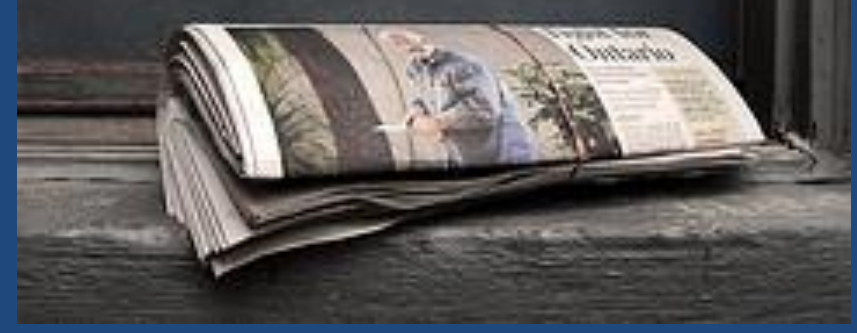

\section{At Our Digital Doorstep Every Day}

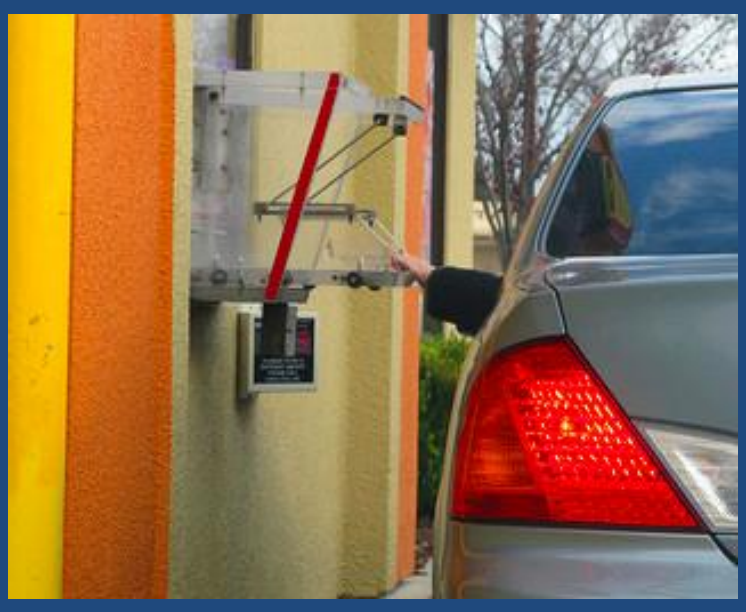

\author{
QUICKLY \\ $=$ \\ 1-3 Clicks
}

(top) image courtesy of Faramaz Hashemi http://www.flickr.com/photos/fhashemi/8 4663672/

(left) image courtesy of Robert Couse-

Baker

http://www.flickr.com/photos/29233640@ N07/3121350629/ 


\section{Easier Said \\ Than Done.}




\section{Format/Device Landscape}

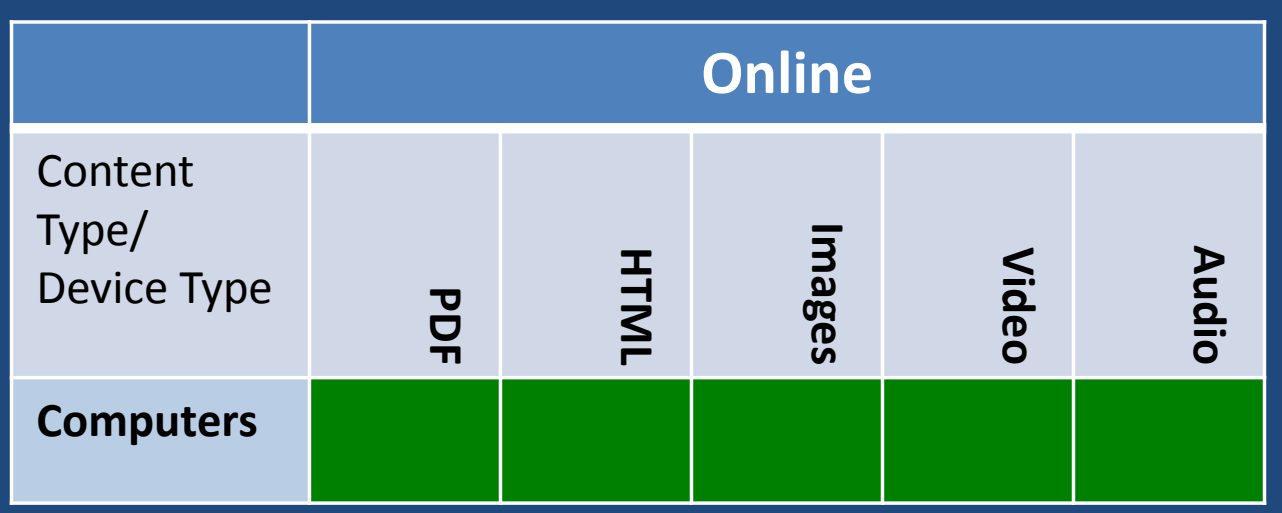




\section{Format/Device Landscape}

\begin{tabular}{|c|c|c|c|c|c|c|c|c|c|c|c|c|}
\hline & \multicolumn{6}{|c|}{ Online } & \multicolumn{6}{|c|}{ Offline } \\
\hline $\begin{array}{l}\text { Content } \\
\text { Type/ } \\
\text { Device } \\
\text { Type }\end{array}$ & तृ & $\stackrel{\underline{z}}{\underline{3}}$ & 罟 & 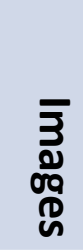 & $\frac{5}{\frac{0}{0}}$ & $\frac{D}{c}$ & 뮤 & $\stackrel{\underline{1}}{3}$ & 罳 & $\begin{array}{l}\overline{3} \\
\stackrel{2}{0} \\
\text { og } \\
0 \\
0\end{array}$ & $\frac{5}{\frac{0}{8}}$ & 흠 \\
\hline Computer & & & & & & & & & & & & \\
\hline Tablets & & & & & & & & & & & & \\
\hline $\begin{array}{l}\text { Smart- } \\
\text { phones }\end{array}$ & & & & & & & & & & & & \\
\hline $\begin{array}{l}\text { ADE } \\
\text { eReaders }\end{array}$ & & & & & & & & & & & & \\
\hline iPod & & & & & & & & & & & & \\
\hline $\begin{array}{l}\text { WMA/MP } \\
3 \text { Players }\end{array}$ & & & & & & & & & & & & \\
\hline $\begin{array}{l}\text { Web- } \\
\text { enabled } \\
\text { eReaders }\end{array}$ & & & & & & & & & & & & \\
\hline
\end{tabular}




\section{Challenges to "Easily \& Quickly"}

- Proprietary content formats $\&$ device types

- Multiple content formats

- Multiple platforms

- DRM requirements

- Inconsistent accessibility support

- Inconsistent internationalization support 
But Easier \& Quicker is Possible, With Forethought And Planning. 


\section{Meeting Your Library Patrons in Their Digital Workflow}

- Understand patrons' digital behaviors

- Understand socioeconomic patterns of content usage and Internet access

- Income

- Education level

- Age

- Physical Abilities
- Prioritize patrons' mostused

- Content

- Devices

- Operating Systems

- Meet them in their most frequent digital workflows

- Or ensure the reward exceeds the effort of learning a new path or workflow 
FINDING THE MUSIC IN THE CACOPHONY 
What are libraries doing with portable devices?

- Kindles, Nooks, other e-readers

- iPads and other tablets

- iPods

- Rule of the day is experimentation

- Pitfalls 


\section{E-readers}

- Represent more complexity because content must be acquired and maintained

- Issues with credit card security

- Licensing issues

- Devices marketed for consumers, not for library use

- How they work with eBook platforms such as Overdrive, 3-M Cloud, EBSCOhost, ebrary, etc. 


\section{Nooks, iPads and Kindles}

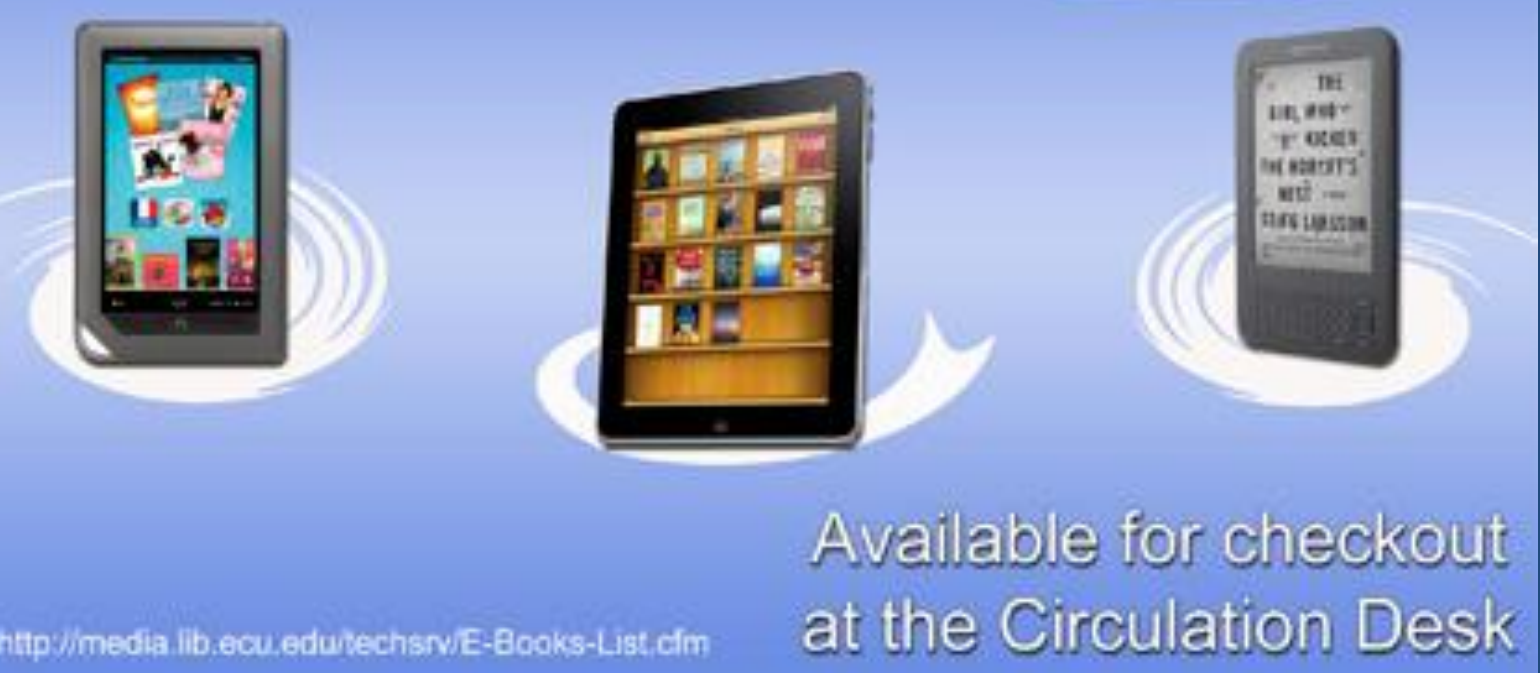




\section{Examples of device lending in libraries}

NC State University

Duke University

Wright State University

East Carolina University

Oregon State University 


\section{iPads \& other tablets}

- Managed more like laptops, i.e. wiped clean after each circulation

- No eBook or other content maintained on these devices

- Apps added based on perceived need and/or repeated requests 
How Mobile impacts library services, reading styles, cultural implications

- Marshall McLuhan: The medium is the message Understanding media (1964)

- People get caught up in the content afforded by new media. However, "What both enthusiast and skeptic miss is what McLuhan saw: that in the long run a medium's content matters less than the medium itself in influencing how we think and act." P.3 The Shallows 


\section{How changed is the way we think \& process information?}

- Neuroplasticity: The ability of the brain to reroute damaged connections, compensate for the lack of vision, hearing, etc. Plastic does not mean elastic. Not all changes and adaptations are necessarily useful or beneficial.

- Hypertext links slows down reading comprehension \& serves to distract, according to numerous studies

- The switch from true reading to "powerbrowsing" has happened very quickly. 
"Overreliance on electronic

information aids can result in a

disuse atrophy of your memory

powers." (p.2 Restak) 


\section{Analogue vs. Digital thinking}

- Memorization as a learning tool -- a thing of the past

- Commonplace books $\rightarrow$ Pinterest

- Passing notes in school $\rightarrow$ Texting

- Letter writing $\rightarrow$ Facebook

- Columns vs. Blogs (See NASIG proceedings, 2007 - Scherlen \& Nardini) 


\section{Examples of Mobile Web Sites}

http://www.simmons.edu/library/m/

http://simmons.libguides.com/content mobile.php?pi $\mathrm{d}=284111 \&$ sid $=2338906$

http://m.library.illinois.edu/

http://m.library.illinois.edu/dbs.asp

http://m.lib.ncsu.edu/

http://m.library.rice.edu/articles.html

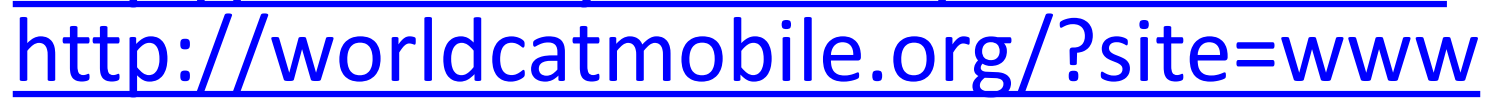

http://books.google.com/m

http://m.hathitrust.org/

http://mobile.jstor.org/

http://pubmedhh.nlm.nih.gov/ 
AUDIENCE Q \& A 


\section{Questions/Comments?}

\section{Eleanor I. Cook}

Assistant Director for Collections \& Technical Services

Academic Library Services -- Joyner Library

East Carolina University

cooke@ecu.edu

Megan Hurst

Product Manager - Library User Experience

EBSCO Publishing

mhurst@ebscohost.com

@MHzUX 